\title{
The role of Market Orientation and Innovation in Improving Business Performance of the Banking Industry
}

\author{
Arman Mohajer Milani ${ }^{1}$ and Shahram Salavati ${ }^{2 *}$
}

\begin{abstract}
This research aims to investigate the mediating role of innovation in the relationship between marketing orientation and business performance of the banking industry. Data were collected through a questionnaire from directors and deputies at Sina Bank branches in Tehran. Reliability of the questionnaire before distribution was calculated based on Cronbach's alpha method and necessary corrections were made. Structural equation modeling was used to analyze the data. The results indicated that there is a significant relationship relationship between market orientation and business performance with regard to the role of mediator of innovation and tendency to learn in branches of Sina Bank in Tehran. There is a significant relationship between market orientation and business performance, with regard to the role of mediators of innovation and tendency to learn in Sina Bank branches in Tehran. There is a significant relationship between market orientation and tendency to learn, there is a significant relationship between market orientation and innovation. There is a significant relationship between tendency to learn and innovation; there is a significant relationship between innovation and business performance; mediator innovation is the relationship between market orientation and business performance. Tendency to learn is the mediator between innovation and market orientation. Moreover, the results show that there is no significant relationship between market orientation and business performance. The most intense relationship is related to market orientation and tendency to learn while the weakest is observed between market orientation and business performance with regard to mediating role of innovation and the tendency to learn.
\end{abstract}

Keywords: Market orientation, business performance, Tendency to learn, Innovation.

\section{Introduction}

Performance is one of the most important constituents of the case in management research; it is undoubtedly the most important criterion for measuring success in business firms [18]. Business performance is defined as the success of a firm in achieving organizational goals related to growth in sales, profitability, and market share. Business performance is structured in two dimensions. One dimension is the objective function that includes financial and market-based factors such as profitability, market share and return on investment. Next, a performance judge that includes factors that focus on customers and employees such as service quality, customer satisfaction, and employee satisfaction [7]. Considering the importance of business performance, many models including Mahmoud et al. [10] have examined the factors affecting business

\footnotetext{
| 1 Department of Business Administration, Tonekabon Branch,Islamic Azad University, Tonekabon, Iran.

${ }^{2}$ Assistant Professor, Department of Business Administration, Tonekabon Branch, Islamic Azad University, Tonekabon, Iran.

*Corresponding Author
} 
performance. The studied factors in the present stucy are innovation, market orientation, and tendency to learn. Innovation is a value-added activity that stimulates performance and business growth [15]. Innovation is recognized as a powerful empowerer for the organization. Innovation can not only improve the optimal use of existing resources as well as the productivity and potential value of the organization, but can also result in intangible assets in the organization. Innovative companies will be successful due to responding to customer needs and improving new capabilities that allow them to achieve superior or more profitable performance [16]. Innovation is considered as an important force for the development of companies and improving their performance. Innovation ability is the most important determinant of performance [17].

The market orientation is known as a degree for the organization to access and use information from its customers as well as to develop and implement a strategy that meets the needs and aspirations of its customers [13].

Strong market orientation along with strengthening the efforts to deliver higher value to the customer will result in a competitive advantage and profitability over competitors. Market orientation increases the performance of an organization in terms of return on investment, profit, sales volume, market share, and sales growth [18]. The tendency to learn is a virtue that guides corporate behavior, processes for access to diverse information, the development of a shared understanding of information obtained by the company and the production of new knowledge or new organizational insights in the company [10]. The more business learning is promoted in the enterprise, the higher will be business performance through improving the technical skills and knowledge of employees in the organization [12].

Banks are financial institutions that collect assets from a variety of sources and allocate them to sectors that need liquidity. Therefore, banks are the vital artery of each country. Due to the entry of private banks into financial markets, the demand for a variety of banking services has also increased dramatically. Banks seek to use a variety of ways to improve their performance in attracting customers to succeed to increase market share and profitability. In this regard, the present research tries to answer whether market orientation can have a significant impact on business performance of Sina bank branches in Tehran with regard to the mediating role of innovation.

\section{Theoretical Foundations}

Business performance: business performance is called by different names, such as operational performance management, organization performance management, or performance management; but all have one meaning: a group of processes aimed at directing business performance through careful analysis as well as organization and automation of principles, standards, and business systems. A business strategy is to help organizations to maximize the use of their resources (human resources and material resources) and, in a more effective and time-efficient way, produce goods and services. How can organizations measure and evaluate performance? Performance is a broad concept that includes productions of a company and the areas with which it interacts [1]. Performance is an indicator that measures the way an organization or institution realizes its goals [6]. 
Innovation: Innovation can be defined as new combinations. It contains not only the creation of these new compounds but also the distribution and use of them in the process of innovation [2]. Organizational innovation is regarded as an innovative management practices and procedures, which are responsive to environmental changes, especially the use of new technologies. Organizational innovation is to adopt an opinion or behavior that is new to the industry, market, or the environment [9]. Organizational innovation can be understood as the process by which inventions are transformed into products, processes, services, or organizational changes with value added available on the market.

Importance of Market Orientation: The role of marketing orientation as a prelude to business performance has been widely addressed in various fields. Marketing orientation is the operational guidance of the marketing concept and it is used to improve business performance. Through the marketing orientation, organizations are able to operate the concept of marketing [5]. Marketing orientation allows companies to develop their ability to collect and process their market information. This ability increases organizational innovation, and this innovation also increases business performance [14].

\section{Literature Review}

Farouk et al [3] conducted a research titled "HRM practices and organizational performance in the UAE banking sector: The mediating role of organizational innovation". This research aimed to examine the impact of human resource management (HRM) practices on organizational performance in the banking sector in the United Arab Emirates (UAE), to test the mediating impact of organizational innovation on the HRMorganizational performance relationship, and to test HRM practices as mediator of the relationship between innovation strategy and organizational innovation. Data were collected from 168 managers working in UAE banks. Results found that organizational innovation fully mediates HRM-organizational performance link. Moreover, with the existence of innovation strategy, HRM mediates the relationship between innovation strategy and organizational innovation. In 2015, Omri conducted a research title "Innovative behavior and venture performance of SMEs: The moderating effect of environmental dynamism." The purpose of this paper is to explore the relationship between innovative behavior and firm performance to determine empirically whether managers' innovative behavior affects directly or indirectly on firm performance through innovative output. A proposed conceptual model is tested with the moderating effects of environmental dynamism. An empirical study tests the conceptual model of a multiindustry sample of Tunisian small and medium-sized enterprises. Empirical findings reveal that innovative behavior acts on innovation output thus having a positive and significant effect on business performance. In "Gaining competitive advantage, improving business performance through customer orientation, differentiating innovation and market distinction in selection of Private Banks of Mazandaran Province", Ismaili and Garmroodi Moghadam [8] conducted a research to examine achieving competitive advantage, improving business performance through customer orientation, differentiating innovation and market differentiation in a selection of private banks in Mazandaran province. This research was a descriptive survey that 400 
questionnaires distributed among non-probable-class customers. It was defined by structural model and analyzed using LISREL software. Results of the research showed that customer orientation has a positive and significant effect on innovation and marketing. In addition, innovation and marketing have a positive and significant impact on business performance.

\section{Research Methodology}

This correlation is an applied research in terms of its objective, survey in terms of data collection method, and descriptive in terms of method. The statistical population of the research is Sina Bank branches in Tehran with 62 branches. In the present study, samples of the population are selected for finite population. The sample size was obtained by the Cochran formula. Simple random sampling method has been used for this research. Since Sina Bank Branches were study case of this research, researchers distributed the questionnaire among the managers and deputies of each branch considering the fact that the method of data collection was through questionnaires. With regard to 54 branches as a sample, 108 questionnaires were distributed; all questionnaires were collected. To evaluate the validity of the tool, two methods of construct validity using factor analysis as well as formal and content validity have been used. Cronbach's alpha coefficient is used to determine the reliability of the questionnaire. Cronbach's alpha is a credit factor that reflects the positive correlation of a set together. Cronbach's alpha is calculated in terms of the mean of internal consistency among questions that measure a concept. The more Cronbach's alpha is closer to 1, the greater the reliability of internal consistency. In this method, if alpha coefficient is less than 0.6, its validity is considered weak, range of 0.7 is acceptable and more than 0.8 is considered good.

Table 1. Reliability of the Questionnaire

\begin{tabular}{|l|l|}
\hline Variable & Alpha coefficient \\
\hline Business Performance & 0.85 \\
\hline Innovation & 0.84 \\
\hline Market orientation & 0.90 \\
\hline Tendency to learn & 0.85 \\
\hline
\end{tabular}

SPSS and SMART PLS2 software have been used to analyze the data. Descriptive and inferential statistics were used to analyze the data in this research.

\section{Research Findings}

\subsection{Description of Research Variables}

According to Figure 1 and Table 1, it is observed that innovation variable has the minimum value of 1.60 , the maximum value is 5.00 , the mean is 3.45 , the standard deviation is 0.75377 , and the variance is 0.568 . Moreover, it is observed that market orientation has the minimum value of 1.50 , the maximum value is 5.00 , the mean is 3.50 , the standard deviation is 0.72030 , and the variance is 0.519 . 
According to Figure 1 and Table 1, it is observed that variable of tendency to learn has the minimum value of 1.64 , the maximum value is 5.00 , the mean is 3.46 , the standard deviation is 0.73562 , and the variance is 0.541 . Moreover, it is observed that business performance has the minimum value of 1.40 , the maximum value is 5.00 , the mean is 3.69 , the standard deviation is 0.78835 , and the variance is 0.621 .

Table 2. Description of research variables

\begin{tabular}{|l|l|l|l|l|l|l|}
\hline Variable & Number & minimum & maximum & Mean & $\begin{array}{l}\text { standard } \\
\text { deviation }\end{array}$ & variance \\
\hline Innovation & 54 & 1.60 & 5.00 & 3.45 & 0.75 & 0.56 \\
\hline $\begin{array}{l}\text { Market } \\
\text { orientation }\end{array}$ & 277 & 1.50 & 5.00 & 3.50 & 0.72 & 0.51 \\
\hline Tendency to learn & 54 & 1.64 & 5.00 & 3.46 & 0.73 & 0.54 \\
\hline $\begin{array}{l}\text { Business } \\
\text { performance }\end{array}$ & 54 & 1.40 & 5.00 & 3.69 & 0.78 & 0.62 \\
\hline
\end{tabular}

\subsection{Normality Test}

In choosing a test, it must be decided whether to use parametric tests or nonparametric tests. One of the main criteria for this selection is the KolmogorovSmirnov test. Kolmogorov-Smirnov test shows the normal distribution of data. In other words, it compares distribution of an attribute in a sample with a distribution assumed to the community. If the data has a normal distribution, then there is a possibility of using the parametric test, otherwise a nonparametric test should be used. After analyzing by SPSS in the output of the Kolmogorov-Smirnov test, if the test was significant (significance level was less than 0.05), it means that the distribution is not normal and a nonparametric test should be used. Therefore, parametric tests cannot be used if the result of this test is not significant.

Table 3. Kolmogorov-Smirnov test for research variables

\begin{tabular}{|l|l|l|}
\hline Variables & Test statistics & Significance level \\
\hline business performance & 1.065 & 0.207 \\
\hline Innovation & 0.939 & 0.342 \\
\hline Tendency to learn & 0.503 & 0.962 \\
\hline Market orientation & 0.730 & 0.661 \\
\hline
\end{tabular}

According to Table (2), it is observed that the significant level obtained for the Kolmogorov-Smirnov test in relation to the research variables is less than 0.05. Thus, research variables have normal distribution.

\subsection{Inferential Statistics}

Due to few number of sample sizes, structural equation modeling with partial least squares approach (PLS) and Smart PLS software are used to test the hypotheses. Data analysis will be performed according to data analysis algorithm in partial least squares method that includes two parts of "fit of the model" and "testing research hypotheses". Before entering the data analysis stage, the titles allocated to the research variables were described in Table (2). 
Table 4. Title of the variables in the model

\begin{tabular}{|l|l|}
\hline Variable & Title in the model \\
\hline business performance & BSNS.PRF \\
\hline Innovation & INOV \\
\hline Tendency to learn & L.O \\
\hline Market orientation & M.O \\
\hline
\end{tabular}

\subsubsection{Research Model Fit}

The fitting of the model is performed out in three parts of the measurement model, structural model and general model. It examines the extent to which research model is compatible with the data collected from the statistical sample. After verifying the fit of the model, the researcher is allowed to examine and test the research hypotheses. After obtaining data about the variables, PLS software provides the final model of the research that covers most of the analysis, in the form of Figure 1 for the estimation of standardized coefficients and Figure 2 for the t significance coefficients. All analyzes and fitting of measurement, structural and general models, and hypothesis testing are performed based on these outputs.

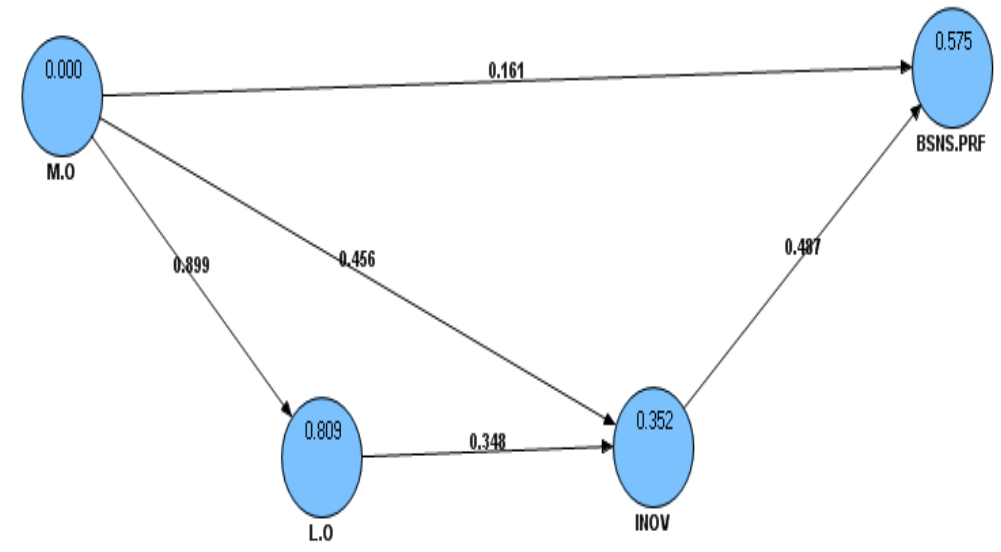

Figure 1. The final model of the research in the estimation of standardized coefficients

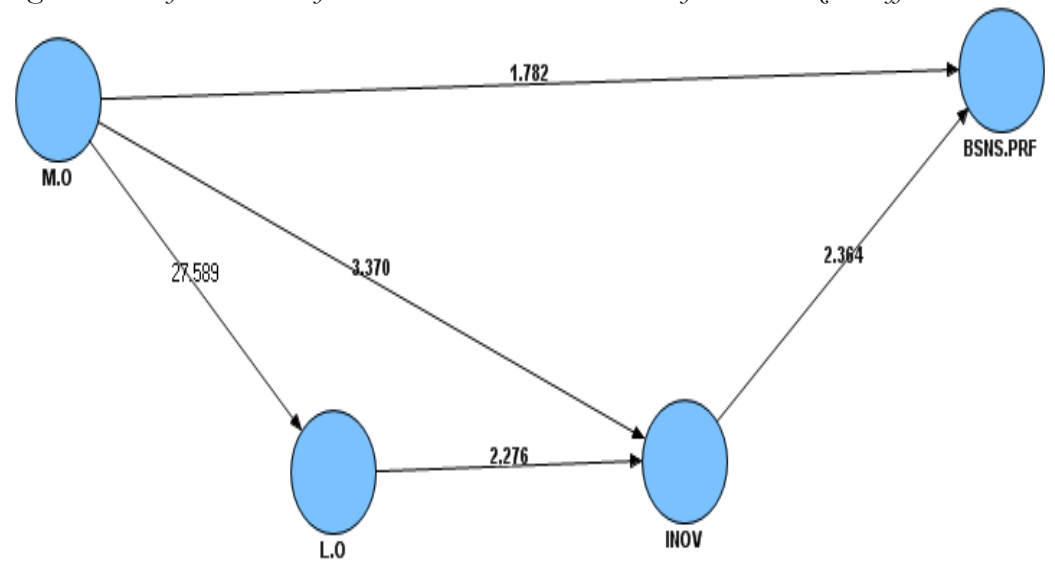

Figure 2. The final model of the research in the estimation of t-significance coefficients 


\subsubsection{Research Measurement Models Fit}

In order to study the fit of the model, three indicators of reliability, convergent validity and divergent validity are used. Indicator reliability is measured by three factors: factor load factor, Cronbach's alpha, and composite reliability.

\section{A. Factor Loads Coefficients}

Factor loads are calculated by calculating the correlation between the indices of a construct and the construct itself. Value of 0.5 for these coefficients confirms that variance between the construct and their index is greater than the variance of the error of measuring of the construct; hence, reliability of this model is acceptable.

Table 5. Factor load coefficients of model constructs

\begin{tabular}{|c|c|c|c|c|}
\hline $\begin{array}{l}\text { Variables } \\
\text { Questions }\end{array}$ & $\begin{array}{l}\text { business } \\
\text { performance }\end{array}$ & Innovation & $\begin{array}{l}\text { Tendency to } \\
\text { learn }\end{array}$ & $\begin{array}{c}\text { Market } \\
\text { orientation }\end{array}$ \\
\hline b.prf1 & 0.79 & & & \\
\hline b.prf2 & 0.88 & & & \\
\hline b.prf3 & 0.88 & & & \\
\hline b.prf4 & 0.88 & & & \\
\hline b.prf5 & 0.84 & & & \\
\hline inov1 & & 0.822 & & \\
\hline inov2 & & 0.72 & & \\
\hline inov3 & & 0.83 & & \\
\hline inov4 & & 0.70 & & \\
\hline inov5 & & 0.81 & & \\
\hline 1.01 & & & 0.78 & \\
\hline 1.010 & & & 0.87 & \\
\hline 1.011 & & & 0.77 & \\
\hline 1.012 & & & 0.81 & \\
\hline 1.013 & & & 0.80 & \\
\hline 1.014 & & & 0.85 & \\
\hline 1.02 & & & 0.70 & \\
\hline 1.03 & & & 0.75 & \\
\hline 1.04 & & & 0.80 & \\
\hline 1.05 & & & 0.79 & \\
\hline 1.06 & & & 0.80 & \\
\hline 1.07 & & & 0.73 & \\
\hline 1.08 & & & 0.84 & \\
\hline 1.09 & & & 0.79 & \\
\hline \multicolumn{5}{|l|}{ m.o1 } \\
\hline \multicolumn{5}{|l|}{ m.o10 } \\
\hline \multicolumn{5}{|l|}{ m.o11 } \\
\hline m.o12 & & & & 0.83 \\
\hline m.o13 & & & & 0.85 \\
\hline m.o14 & & & & 0.83 \\
\hline m.o15 & & & & 0.80 \\
\hline
\end{tabular}




\begin{tabular}{|l|l|l|l|l|}
\hline m.o16 & & & & 0.83 \\
\hline m.o17 & & & & 0.80 \\
\hline m.o18 & & & & 0.74 \\
\hline m.o19 & & & & 0.81 \\
\hline m.o2 & & & & 0.82 \\
\hline m.o20 & & & & 0.73 \\
\hline m.o21 & & & & 0.82 \\
\hline m.o22 & & & & 0.82 \\
\hline m.o23 & & & & 0.79 \\
\hline m.o24 & & & & 0.70 \\
\hline m.o3 & & & & 0.73 \\
\hline m.o4 & & & & 0.69 \\
\hline m.o5 & & & & 0.60 \\
\hline m.o6 & & & & 0.83 \\
\hline m.o7 & & & 0.82 \\
\hline m.o8 & & & 0.83 \\
\hline m.o9 & & & 0.65 \\
\hline
\end{tabular}

As observed, load factor values are greater than 0.5 in all constructs. Therefore, the reliability of measurement models is acceptable, which indicates the fitting of the model of measurement.

\section{B. Cronbach's Alpha and Composite Reliability}

According to the data analysis algorithm in partial least squares method (PLS), it is now time to study the Cronbach's alpha coefficients and composite reliability. Cronbach's alpha coefficients and composite reliability of the constructs represent the ratio of variance between each construct and its indices to the total variance of the construct. The reliability coefficient above 0.7 is known as acceptable. The results of the study of reliability coefficients are presented in Table (5). According to the results seen in Table 5, all factors have acceptable composite reliability coefficients. Cronbach's reliability coefficient is also acceptable. Therefore, it can be concluded that the research questionnaire has a good reliability. As a result of the suitability of the measurement model, it is also confirmed.

Table 6. Reliability of the questionnaire

\begin{tabular}{|l|l|l|}
\hline Variable & \multicolumn{1}{|c|}{$\begin{array}{c}\text { Cronbach's alpha } \\
\boldsymbol{\alpha}>0.7\end{array}$} & \multicolumn{1}{c|}{$\begin{array}{c}\text { composite reliability } \\
\boldsymbol{C R}>0.7\end{array}$} \\
\hline Business performance & 0.881278 & 0.893967 \\
\hline Innovation & 0.839238 & 0.8863 \\
\hline Tendency to learn & 0.905396 & 0.920379 \\
\hline Market orientation & 0.92299 & 0.935018 \\
\hline
\end{tabular}

In this study, the average variance extracted (AVE) is used in order to verify convergent validity. AVE shows the correlation of a construct with its indexes. Fornell and Larcker [4] have introduced this criterion to measure convergent validity; they argue that critical 
value of this value is 0.5 . This means that a value above 0.5 shows acceptable convergent validity. The results of examining convergent validity of the model constructs are presented in Table 6.

Table 7. Convergent validity of model constructs based on AVE

\begin{tabular}{|l|l|}
\hline Variable & AVE \\
\hline Business performance & 0.739122 \\
\hline Innovation & 0.610325 \\
\hline Tendency to learn & 0.634566 \\
\hline Market orientation & 0.62077 \\
\hline
\end{tabular}

As seen in the table, the AVE value for all constructs of the model is in a rate less than 0.5 , thus the convergent validity of the model and the fitting of the measurement models are confirmed.

In order to show the independence of the concepts used in the study, Fornell and Larcker, divergent validity has been used; the results are presented in the following table. As shown in Table 7, the value of the AVE square (numbers on the main diameter) for all the latent variables of the research is greater than the correlation between them and other variations; this indicates divergent validity of the measurement models.

Table 8 . The results of the study of the divergent validity of the model based on the Fornell and Larcker's matrices

\begin{tabular}{|l|l|l|l|l|}
\hline Variables & $\mathbf{1}$ & $\mathbf{2}$ & $\mathbf{3}$ & $\mathbf{4}$ \\
\hline Business performance & 0.86 & & & \\
\hline Innovation & 0.70 & 0.78 & & \\
\hline Tendency to learn & 0.64 & 0.56 & 0.80 & \\
\hline Market orientation & 0.65 & 0.59 & 0.76 & 0.79 \\
\hline
\end{tabular}

\subsection{Structural Model Fit}

In accordance with the algorithm for data analysis in the PLS method, after fitting the measurement models, it is time to fit the structural model of the research. In this section, R-Squares criterion is used to fit the structural part.

\subsubsection{R-Square Criterion}

$\mathrm{R} 2$ is a criterion for linking the measurement part to the structural part of the model and shows the effect that an exogenous variable has on an endogenous variable. The values of $0.19,0.33$, and 0.67 were introduced as weak, moderate, and strong R2 values respectively. The results of this criterion are presented in Table 8.

Table 9. Convergent validity of model constructs based on $\mathrm{R} 2$ values

\begin{tabular}{|l|l|}
\hline Variable & R2 Values \\
\hline business performance & 0.574854 \\
\hline innovation & 0.35192 \\
\hline Tendency to learn & 0.80888 \\
\hline Market orientation & --- \\
\hline
\end{tabular}


According to table (8), the obtained value of $\mathrm{R} 2$ according to the three values of the criterion indicates that the fit is relatively suitable for the structural model. The values indicate that the model explains and accounts for $57.5 \%$ of the business performance variable.

\subsubsection{Q2 Criterion}

The Q2 benchmark is introduced by Stone and Casey (1975), which outlines the predictive power of the model. They believe that models with acceptable structural fit should have the ability to predict indices related to the model's intrinsic constructs. The Q2 value must be calculated for all of the model's intrinsic constructs. The Q2 values for all of the in-model variables are presented in Table 9.

Table 10. Q2 value

\begin{tabular}{|l|l|}
\hline Variable & Q2 values \\
\hline business performance & 0.411718 \\
\hline Innovation & 0.211826 \\
\hline Tendency to learn & 0.511633 \\
\hline Market orientation & --- \\
\hline
\end{tabular}

According to the values obtained for $\mathrm{Q} 2$ and the three values of $0.02,0.15$, and 0.30 , respectively, as weak, moderate, and strong values for the predicted power intensity, as determined by Hensler et al. (2009), respectively, the predictive power for the present model variables is appropriate and acceptable; proper fit of the structural model is confirmed.

\subsubsection{Redundancy Criterion}

Redundancy is the last criterion to measure fitness in the structural part. This criterion represents the amount of variability in the indices of an endogenous construct that is affected by one or more external constructs. It is calculated by multiplying R2 values in communalities. The values of the redundancy of the intrinsic variables of the research are visible in Table 10.

Table 11. Redundancy values of model constructs

\begin{tabular}{|l|l|}
\hline Variable & Redundancy values \\
\hline Business performance & 0.327858 \\
\hline Innovation & 0.187542 \\
\hline Tendency to learn & 0.511649 \\
\hline Market orientation & ---- \\
\hline
\end{tabular}

$\overline{\text { Redundancy }}=0.342$

The average values of the redundancy of the intrinsic models in this study were 0.342 . The benchmark for this criterion has not been quantified and is only considered for the GOF benchmark calculation. 


\subsubsection{General Model Fit}

The fit of a general model is evaluated based on the GOF criterion. Regarding the average of the communalities of the construct (first order communalities of the construct) and the mean of R2 for all the intrinsic constructs of the model, GOF value for the general fit of the present research model is:

$$
\text { GOF }=\sqrt{\overline{\text { Communalities }} \times \overline{R^{2}}}=\sqrt{0.578 \times 0.651}=0.613
$$

According to the three values of $0.01,0.25$, and 0.36 , as weak, moderate, and strong values, value of 0.613 for GOF indicates a strong overall fit of the research model.

\subsection{Hypothesis Testing}

A significant coefficient determines significance of the effects of variables, and confirmation / non-confirmation of research hypotheses. Moreover, the standardized coefficients of the paths also determine the effect of the variables on each other. Before examining the research hypotheses, the coefficients of indirect paths in the model will be studied.

Table 12. Effects of indirect path coefficients

\begin{tabular}{|lll|l|}
\hline Direct Paths & & $\begin{array}{l}\text { Indirect } \\
\text { effects }\end{array}$ \\
\hline $\begin{array}{l}\text { Market } \\
\text { orientation }\end{array}$ & $\begin{array}{l}\text { Tendency } \\
\text { learn }\end{array}$ & to $\longrightarrow$ innovation $\rightarrow \begin{array}{l}\text { Business } \\
\text { performance }\end{array}$ & 0.152 \\
\hline Market orientation & $\longrightarrow$ inovation $\longrightarrow$ Business performance & 0.222 \\
\hline
\end{tabular}

Depending on the results of the indirect path analysis, it is clear that indirect impact of market orientation on business performance through tendency to learn and innovation is equal to 0.152 . Moreover, indirect impact of market orientation on business performance through innovation is equal to 0.222 .

Main hypothesis: there is a significant relationship between market orientation and business performance with regard to the mediating role of innovation and the tendency to learn in Sina Bank branches in Tehran.

According to the structural model of the research, in the case of significant coefficients, the amount of t-statistics corresponding to paths of market orientation with tendency to learn, tendency to learn with innovation, and innovation with business performance are out of range $(-1.96 \& 1.96)$. Thus, the research hypothesis is accepted. Besides, the relationship between market orientation and business performance with respect to the mediating role of innovation and tendency to learn in Sina Bank branches in Tehran is equal to 0.152. In addition, results indicate that the direct relationship between market orientation and performance is not met; hence, innovation and the tendency to learn have a full mediating role.

First secondary hypothesis: there is a significant relationship between market orientation and business performance.

According to the structural model of the research, in the case of significant coefficients, it is observed that t-statistic between two variables of market orientation and business 
performance is within the range $(-1.96 \& 1.96)$. Therefore, the hypothesis is not accepted.

Table 13. Results of analyzing first research bypothesis

\begin{tabular}{|c|c|c|c|c|c|c|}
\hline \multicolumn{4}{|c|}{ Research hypothesis } & & Standard path & Test result \\
\hline $\mathrm{H} 1$ & $\begin{array}{l}\text { Market } \\
\text { orientation }\end{array}$ & $\rightarrow$ & $\begin{array}{l}\text { Business } \\
\text { performance }\end{array}$ & 1.782 & 0.161 & $\begin{array}{l}\text { Non- } \\
\text { confirmation }\end{array}$ \\
\hline
\end{tabular}

Second secondary hypothesis: there is a significant relationship between market orientation and tendency to learn.

According to the structural model of the research, in the case of significant coefficients, it is observed that t-statistic between two variables of market orientation and tendency to learn is out of the range $(-1.96 \& 1.96)$. Therefore, the hypothesis is accepted. Ratio of relationship between market orientation and tendency to learn is also equal to 0.899 .

Table 14. Results of analyzing second research bypothesis

\begin{tabular}{|l|l|l|l|l|l|l|}
\hline \multicolumn{2}{|l|}{ Research hypothesis } & $\begin{array}{l}\text { T- } \\
\text { value }\end{array}$ & $\begin{array}{l}\text { Standard path } \\
\text { coefficient }\end{array}$ & Test result \\
\hline H2 & $\begin{array}{l}\text { Market } \\
\text { orientation }\end{array}$ & $\rightarrow$ & $\begin{array}{l}\text { Tendency to } \\
\text { learn }\end{array}$ & 27.589 & 0.899 & Confirmation \\
\hline
\end{tabular}

Third secondary hypothesis: there is a significant relationship between market orientation and innovation.

According to the structural model of the research, in the case of significant coefficients, it is observed that t-statistic between two variables of market orientation and innovation is out of the range $(-1.96 \& 1.96)$. Therefore, the hypothesis is accepted. Ratio of relationship between market orientation and innovation is also equal to 0.456 .

Table 15. Results of analyzing third research bypothesis

\begin{tabular}{|l|l|l|l|l|l|l|}
\hline \multicolumn{2}{|l|}{ Research hypothesis } & $\begin{array}{l}\text { T- } \\
\text { value }\end{array}$ & $\begin{array}{l}\text { Standard path } \\
\text { coefficient }\end{array}$ & Test result \\
\hline H3 & $\begin{array}{l}\text { Market } \\
\text { orientation }\end{array}$ & $\rightarrow$ & Innovation & 3.370 & 0.456 & Confirmation \\
\hline
\end{tabular}

Fourth secondary hypothesis: there is a significant relationship between tendency to learn and innovation.

According to the structural model of the research, in the case of significant coefficients, it is observed that t-statistic between two variables of tendency to learn and innovation is out of the range $(-1.96 \& 1.96)$. Therefore, the hypothesis is accepted. Ratio of relationship between tendency to learn and innovation is also equal to 0.348 .

Table 16. Results of analyzing fourth research bypothesis

\begin{tabular}{|l|l|l|l|l|l|}
\hline \multicolumn{2}{|l|}{ Research hypothesis } & $\begin{array}{l}\text { T- } \\
\text { value }\end{array}$ & $\begin{array}{l}\text { Standard } \\
\text { coefficient }\end{array}$ & path & Test result \\
\hline H4 & $\begin{array}{l}\text { Tendency to } \\
\text { learn }\end{array}$ & $\rightarrow$ Innovation & 2.276 & 0.348 & Confirmation \\
\hline
\end{tabular}


Fifth secondary hypothesis: there is a significant relationship between innovation and business performance.

According to the structural model of the research, in the case of significant coefficients, it is observed that t-statistic between two variables of innovation and business performance is out of the range $(-1.96 \& 1.96)$. Therefore, the hypothesis is accepted. Ratio of relationship between innovation and business performance is also equal to 0.487 .

Table 17. Results of analyzing fifth research hypothesis

\begin{tabular}{|l|l|l|l|l|l|}
\hline \multicolumn{2}{|l|}{ Research hypothesis } & $\begin{array}{l}\text { T- } \\
\text { value }\end{array}$ & $\begin{array}{l}\text { Standard path } \\
\text { coefficient }\end{array}$ & Test result \\
\hline H5 & Innovation & $\rightarrow \begin{array}{l}\text { Business } \\
\text { performance }\end{array}$ & 2.364 & 0.487 & Confirmation \\
\hline
\end{tabular}

Sixth secondary hypothesis: innovation is a mediator in the relationship between market orientation and business performance.

According to the structural model of the research, in the case of significant coefficients, it is observed that t-statistic between two variables of market orientation and innovation is out of the range $(-1.96 \& 1.96)$. Therefore, the hypothesis is accepted. Ratio of relationship between market orientation and innovation is also equal to 0.222 . Moreover, since the direct relationship between market orientation and business performance has not been verified, innovation has the full mediating role in the relationship between market orientation and business performance.

Table 18. Results of analyzing sixth research bypothesis

\begin{tabular}{|l|l|l|l|l|l|}
\hline \multicolumn{2}{|l|}{ Research hypothesis } & $\begin{array}{l}\text { T- } \\
\text { value }\end{array}$ & $\begin{array}{l}\text { Standard } \\
\text { path } \\
\text { coefficient }\end{array}$ & Test result \\
\hline H6 & $\begin{array}{l}\text { Market } \\
\text { orientation }\end{array}$ & Innovation & $\begin{array}{l}(3.70) \\
(2.364)\end{array}$ & $\begin{array}{l}\text { Business } \\
\text { performance }\end{array}$ & Confirmation \\
\hline
\end{tabular}

Seventh secondary hypothesis: tendency to learn is a mediator in the relationship between innovation and market orientation.

According to the structural model of the research, in the case of significant coefficients, it is observed that $\mathrm{t}$-statistic between two variables of market orientation and tendency to learn is out of the range $(-1.96 \& 1.96)$. Therefore, the hypothesis is accepted. Ratio of relationship between market orientation and tendency is also equal to 0.313. Moreover, since the direct relationship between innovation and market orientation has not been verified, tendency to learn has the full mediating role in the relationship between innovation and market orientation.

Table 19. Results of analyzing seventh research bypothesis

\begin{tabular}{|l|l|l|l|l|l|}
\hline \multicolumn{2}{|l|}{ Research hypothesis } & T-value & $\begin{array}{l}\text { Standard } \\
\text { path } \\
\text { coefficient }\end{array}$ & Test result \\
\hline H6 & $\begin{array}{l}\text { Market } \\
\text { orientation }\end{array}$ & $\begin{array}{l}\text { tendency } \\
\text { to learn }\end{array}$ & innovation & $\begin{array}{l}(27.589) \\
(2.276)\end{array}$ & 0.313 \\
\hline
\end{tabular}




\section{Conclusion}

Main hypothesis: there is a significant relationship between market orientation and business performance with regard to the mediating role of innovation and the tendency to learn in Sina Bank branches in Tehran. According to the structural model of the research, in the case of significant coefficients, the amount of t-statistics corresponding to paths of market orientation with tendency to learn, tendency to learn with innovation, and innovation with business performance are out of range $(-1.96 \& 1.96)$. Thus, the research hypothesis is accepted. Besides, the relationship between market orientation and business performance with respect to the mediating role of innovation and tendency to learn in Sina Bank branches in Tehran is equal to 0.152. In addition, results indicate that the direct relationship between market orientation and performance is not met; hence, innovation and the tendency to learn have a full mediating role. This result is consistent with research by Mahmoodi et al [11] and the effect of their research was 0.13 , which is less than the present study.

First secondary bypothesis: there is a significant relationship between market orientation and business performance. According to the structural model of the research, in the case of significant coefficients, it is observed that t-statistic between two variables of market orientation and business performance is within the range $(-1.96 \& 1.96)$. Therefore, the hypothesis is not accepted. This result is consistent with research by Mahmoodi et al [11] because they rejected this hypothesis. However, it is not consistent with the findings by Haji Hosseini and Noorzad Moghadam [7] because this hypothesis has been confirmed by them.

Second secondary bypothesis: there is a significant relationship between market orientation and tendency to learn. According to the structural model of the research, in the case of significant coefficients, it is observed that t-statistic between two variables of market orientation and tendency to learn is out of the range $(-1.96 \& 1.96)$. Therefore, the hypothesis is accepted. Ratio of relationship between market orientation and tendency to learn is also equal to 0.899 . This result is consistent with research by Haji Hosseini and Noorzad Moghadam [7]; impact factor of their findings was 0.78 , which is less than the present study.

Third secondary bypothesis: there is a significant relationship between market orientation and innovation. According to the structural model of the research, in the case of significant coefficients, it is observed that t-statistic between two variables of market orientation and innovation is out of the range $(-1.96 \& 1.96)$. Therefore, the hypothesis is accepted. Ratio of relationship between market orientation and innovation is also equal to 0.456 . This result is consistent with research by Mahmoodi et al [11]; impact factor of their findings was 0.48 , which is more than the present study. Moreover, it is in line with the findings by Ismaili and Garmroodi Moghadam [8] while impact factor of their findings was 0.37, which is less than the present study.

Fourth secondary bypothesis: there is a significant relationship between tendency to learn and innovation.According to the structural model of the research, in the case of significant coefficients, it is observed that t-statistic between two variables of tendency to learn and innovation is out of the range $(-1.96 \& 1.96)$. Therefore, the hypothesis is accepted. Ratio of relationship between tendency to learn and innovation is also equal to 0.348 . This 
result is consistent with research by Mahmoodi et al [11]; impact factor of their findings was 0.31 , which is less than the present study.

Fifth secondary bypothesis: there is a significant relationship between innovation and business performance. According to the structural model of the research, in the case of significant coefficients, it is observed that t-statistic between two variables of innovation and business performance is out of the range $(-1.96 \& 1.96)$. Therefore, the hypothesis is accepted. Ratio of relationship between innovation and business performance is also equal to 0.487 . This result is consistent with research by Mahmoodi et al [11]; impact factor of their findings was 0.37 , which is less than the present study. Moreover, it is in line with the findings by Haji Hosseini and Noorzad Moghadam [7] while impact factor of their findings was 0.23 , which is less than the present study.

Sixth secondary bypothesis: innovation is a mediator in the relationship between market orientation and business performance.According to the structural model of the research, in the case of significant coefficients, it is observed that t-statistic between two variables of market orientation and innovation is out of the range $(-1.96 \& 1.96)$. Therefore, the hypothesis is accepted. Ratio of relationship between market orientation and innovation is also equal to 0.222 . Moreover, since the direct relationship between market orientation and business performance has not been verified, innovation has the full mediating role in the relationship between market orientation and business performance. It is in line with the findings by Haji Hosseini and Noorzad Moghadam [7] as impact factor of their findings was 0.18 , which is less than the present study. It is also consistent with research by Mahmoodi et al [11]; impact factor of their findings was 0.17 , which is less than the present study.

Seventh secondary hypothesis: tendency to learn is a mediator in the relationship between innovation and market orientation. According to the structural model of the research, in the case of significant coefficients, it is observed that t-statistic between two variables of market orientation and tendency to learn is out of the range $(-1.96 \& 1.96)$. Therefore, the hypothesis is accepted. Ratio of relationship between market orientation and tendency is also equal to 0.313. Moreover, since the direct relationship between innovation and market orientation has not been verified, tendency to learn has the full mediating role in the relationship between innovation and market orientation. This result is consistent with research by Mahmoodi et al [11]; impact factor of their findings was 0.20 , which is less than the present study.

Considering the significance of the relationship, there is a meaningful relationship between market orientation and tendency to learn. Based on the market orientation indicators, it can be stated that employees' satisfaction survey index has less efficiency in proportion to their performance [14]. In this regard, it is recommended to pay attention to employees' opinion about various work processes and service types in meetings. By organizing regular meetings with staff, Staff comments about customers in different units of the organization are shared. Therefore, staff satisfaction will increase.

\section{References}

1. Arocas, R. and Morley,M. J. (2015), Talent management, talent mindest competency and job performance: the mediating role of job satisfaction, European J. Internatinal Management, Vol. 9, No. 1, pp. 2851 
2. Divandari, A., \& Bagheri, T. (2012). Comparative Study of Iran's Banking Industry with MENA Countries. Development of entrepreneurship, Fifth Volume, issue 3, pp. 145-164.

3. Farouk, S., Abu Elanain, H. M., Obeidat, S. M., \& Al-Nahyan, M. (2016). HRM practices and organizational performance in the UAE banking sector: The mediating role of organizational innovation. International Journal of Productivity and Performance Management, 65(6), 773-791.

4. Fornell, C., \& Larcker, D. F. (1981). Structural equation models with unobservable variables and measurement error: Algebra and statistics. Journal of marketing research, 382-388.

5. Ghareche, M., Karimi Alavije, M., \& Akbarinezhad, M. (2013). Impact of marketing and commercial relations on export performance. New Marketing Research, Third Issue, No. 4, pp. 59-76.

6. Godarzvand Chegini, M., Chirani, I., Moghadam, H., Ghane Koshalshahi, S.F., Moradi, M. (2016). Investigating the Relationship between Talent Management and Organizational Performance. Productivity Management, Vol. 10, No. 38, pp. 253-258.

7. Haji Hosseini, H., \& Noorzad Moghadam, E. (2014). The Effect of Innovation and Market Orientation on Business Performance and Sustainable Competitive Advantage in Industrial Enterprises. Industrial Technology Development Quarterly, No. 23, pp. 22-31.

8. Ismaili, M., \& Garmroodi Moghadam, D. (2016). Gaining competitive advantage, improving business performance through customer orientation, differentiating innovation and market distinction in selection of Private Banks of Mazandaran Province. The First International Conference on the New Paradigms of Business and Organizational Intelligence Management; Tehran, Shahid Beheshti University.

9. Mahdi beigi, N., Kamalian, A., \& Yaghubi, N. (2013). Evaluation of the Effects of Establishment of Organizational Resource Planning System on Organizational Innovation, Public Management Research, Sixth Issue, No. 20, pp. 5-74.

10. Mahmoud, M. A., Blankson, C., Owusu-Frimpong, N., Nwankwo, S., \& Trang, T. P. (2016). Market orientation, learning orientation and business performance: The mediating role of innovation. International Journal of Bank Marketing, 34(5), 623-648.

11. Mahmoodi, M.T., Afzal Kohi, F., \& Foruzandeh, A. (2016). Investigating and evaluating the relationship between organizational learning and organizational innovation among experts of Isfahan University. Educational Management Needs, Issue 11, No. 2, p. 103-120.

12. Mazloomi, N., Zamani, M., Seyyed Naghavi, A., \& Rabani, A. (2013). The relationship of organizational learning, improving interpersonal and interpersonal trust to organizational performance (insurance company representation firms). Insurance Newsletter, Issue 29, No. 2, pp. 163-182.

13. Newman, A., Prajogo, D., \& Atherton, A. (2016). The influence of market orientation on innovation strategies. Journal of service theory and practice, 26(1), 72-90.

14. Rahimi, R., Darvishi, M. (2015). The Effect of Marketing Orientation on Business Performance with the Mediating role of Organizational Innovation (Case Study: Companies Manufacturing and Supplying Parts of the National Iranian Oil Fields in Khuzestan Province). New Marketing Research, Vol. 5, No. 4, pp. 139-162.

15. Raj Rahul, Srivastava Kailash B.L , (2016),"Mediating role of organizational learning on the relationship between market orientation and innovativeness ", The Learning Organization, Vol. 23 Iss 5 pp. $370-384$

16. Shaemi, A., Khazaeipoor, J., Shabani, J., \& Salehzadeh, R. (2012). The Effect of Knowledge Sharing on Innovation and Performance of Small and Medium Enterprises with Balanced Scorecard Approach. Management Improvement and Development, Vol. 23, No. 69, pp. 59-93.

17. smith, A. D. (2011). Competitive approaches to new product development: A comparison of successful organizations in an unstable economic environment. Team Performance Management, 17, 124145

18. Taghavifard, M.T., Behboodi, O., \& Ghafoorian Shagerdi, A. (2015). Investigating the Effect of Market Orientation on Business Performance (Case Study: Manufacturing Companies Accepted in Tehran Stock Exchange). Quarterly Journal of Research in Business Management, Seventh Issue, No. 13, pp. 205-227. 